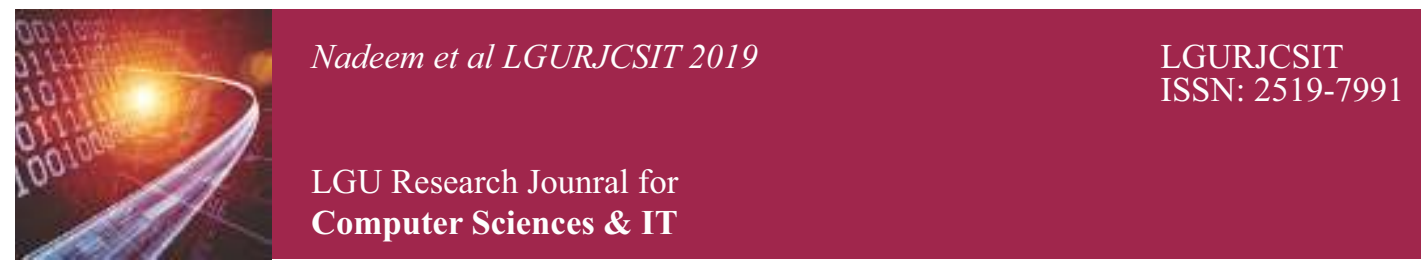

Vol. 3 Issue 1, January - March 2019

\title{
Classification of Water using Mamdani Fuzzy Inference System
}

Waqas Nadeem ${ }^{1}$, Muhammad Sajid Farooq ${ }^{2}$

University of Management and Technology ${ }^{1}$, NCBA\&E Lahore ${ }^{2}$

\begin{abstract}
:
The basic reason to conduct the research and state the problems regarding the contaminated water is to highlight the basic elements that should be available in water and some that are not, to a ratio that the water is declared safe for drinking. To do so we will keep account of the basic elements in water, odor, taste, hardness, $\mathrm{pH}$ level and color of water by following the guidelines given by World Health Organization (WHO) and researches conducted in past on the safe drinking water in Pakistan. Our basic objective is to conclude these mention factors are either in the range of safety parameters or not and also set some of the parameter on which the previous researches in Pakistan are lacking. In past researches the methods used to calculate the values of water were manual but for our research we will use significant software tool for calculations because we want zero tolerance in the output values of elements in the water up to the safety level. The method proposed for this type of research is Fuzzification to calculate the values and measurements of the proposed problem. In this research we are using our computer science expertise combined with mathematical knowledge to provide the solution and these things that set our project apart.
\end{abstract}

Keywords: WHO, MFIS, TDS, pH, Cl, $\mathrm{Na}$

\section{INTRODUCTION}

Drinking water is never pure. Rock, soil and air when comes in contact with water, they naturally add up microorganisms and minerals in the water and some substances may added up due to the activities of humans. It is not necessary for the drinking to be pure as some of the minerals added up naturally are good for health [1]. The Nation Research Council states that drinking water containing Fluoride, existing naturally or added up, helps to minimize tooth decay problems. Calcium and Magnesium dissolved in water may contribute in dietary of human in small amount [2]. It depends on the amount of the substance dissolved in the water to know whether the water is drinkable or not. There are usually two levels set to check and improve the quality of water. The first level aims to consider the use of water by human with no adverse effect and to protect and maintain the function of aquatic ecosystem. In most countries first level corresponds, with the most stringent water quality criterion among all of the considered water uses, to account specific site conditions, some modifications are made. The second level is used to be reached in fixed time duration. The second level is balanced between environmental, economic and technical perspectives and it finally reaches first level using step-by-step approach, possibility of desirable environmental point of view and feasibility of economic and technical point of view is considered [2-3].

Clean water is an importance for health, most people in the developed countries don't know the usage of water much for drinking, and sanitation. In many developing nations the access of clean water and proper sanitation is the major issue which leads to the death of Million people each year due largely preventable diseases caused by unsafe drinking water [1-3].

Accurate automated water classification of the multi-temporal global Landsat archive would facilitate analysis of the changing distribution of water, showing where water is 
permanent or temporary, and allowing research into the long term trends of water extent. This would complement static global water maps that have to date only represented the period circa2000 , such as the global water bodies database [23-24].

\section{SERIOUS CHALLENGES ON HEALTH}

There are many serious challenges that our humanity is facing regarding polluted and unhealthy supply of water from different sources. Some of them are stated as [1][3][6].

- 844 million people lack even a basic drinking-water service, including 159 million people who are dependent on surface water.

- Globally, at least 2 billion people use a drinking water source contaminated with fasces.

- Contaminated water can transmit diseases such diarrhea, cholera, dysentery, typhoid, and polio. Contaminated drinking water is estimated to cause 502000 diarrheal deaths each year.

- By 2025, half of the world's population will be living in water-stressed areas.

- In low- and middle-income countries, 38\% of health care facilities lack an improved water source, $19 \%$ do not have improved sanitation, and $35 \%$ lack water and soap for hand washing.

- About 5,000 children die each day due to preventable diarrheal diseases such as cholera and dysentery, which spread when people use contaminated water for drinking or cooking.

- A lack of water for personal hygiene leads to the spread of totally preventable ailments like trachoma, which has blinded some six million people.

\section{LITERATUREALREVIEW}

Modern researches in defining the standards of water are struggling for getting improved data rates of elements involved in water. Enormous research has already been done in this field over past few years and still today's most attractive topic of research for researchers.

Some of the past researches conducted on water resources in Pakistan are the following. British Geological Survey, Nottingham examined the quality of ground water in Pakistan in 2001 [1]. Laghari, A.N. \& Vanham, D. and Rauch, W examined the Indus basin in the framework of current and future water resources management and published in Hydrological Processes [2]. Muhammad Asiam Tahir, Muhammad Akram, Faizan ul Hasan \&
Muhammad Faroque did a Technical Assessment Survey in Punjab for the provision of safe drinking water resources in 2011 [3]. Qureshi.A. S, McCornick.P.G, Sarwar.A \& Sharma.B.R identified challenges and prospects of sustainable groundwater management in the Indus basin, Pakistan in 2009 [4]. Qureshi, A.S., McCornick P.G., Qadir M. \& Aslam Z in 2008 studied on managing salinity and waterlogging in the Indus basin in Pakistan on Agricultural Water Management [5]. WWF analyzed the situation of water resources of Lahore in 2014 [6]. Aslam, A, assessed the national drinking water quality standards in Pakistan under the support of Sustainable Development Policy Institute(SDPI) in 2016 [7]. Khwaja, MA, Yasmin, F and Habib, K 2011, Access to safe drinking water in city slums through household water treatment systems, Sustainable Development Policy Institute (SDPI), Islamabad. Pakistan [8]. Sulehria, AQK, Mustafa, YS, Kanwal, B, and Nazish, A 2013, Assessment of drinking water in Islampura, Lahore district, Science International [9]. Haydar, S, Arshad, M and Aziz, JA 2009, Evaluation of drinking water quality in urban areas of Pakistan: A case study of southern Lahore. Pakistan journal of engineering and applied sciences [10]. Tahir, M.A et al in 1994 surveyed quality of drinking water in the rural areas of Rawalpindi District under the banner of Pakistan Council of Research in Water Resources, Islamabad, Pakistan [17]. Tahir, MA, Rasheed, H and Imran, S in 2010, Water Quality Status in Rural Areas of Pakistan [11].

These researches have concluded data analysis, results and comparison with water quality standards and also identified them focusing on the water situation in Pakistan but still many global researches had done very well to identify many more aspects regarding the water standards and now we will discuss about them [13]-[19].

Saunders and war ford in 1976, identified and enlisted potential economic effects and health effects of rural water supply systems [20]. Macro-economic effects, such as effects on development and output, improved health, increased time for productive work, increase in income, increase in population and effects related to averted costs to the economy are systematically examined in the book.

World Development Report in 1994 identifies the economic impacts of clean water [20]. It states "more than two million deaths 
from diarrhea could be avoided each year if all people had reasonable water and sanitation services." 53 The report argues that large gains in environmental quality, health, equity, and direct economic returns can be realized by adopting an approach that comprises four key elements namely (1) managing water resources better, (2) providing those private services that people want and are willing to pay, (3) using scarce public funds only for those services that provide wider community benefits and (4) developing flexible responsive institutional mechanisms for providing these services [21].

Zaslow and Herman in 1996, observed effect of contaminants present in drinking water, according to them some of the contaminants are not well studied yet as it is not necessary that every contaminant in the drinking water harms the health, they may be harmful and have some health issues if they exceed some limit. Even though we should consider it as they might lead to some serious health issue like lungs irritation, vomiting, nauseas, skin rash, dizziness and even death. In North Carolina, the drinking water is usually free from any contamination and is of high quality. Water is tested by Public water supplies to make sure that the water is free from any type of contamination. Still some of the private water supplies and wells are not regulated by the authorities to make sure the quality of water, so here it is the responsibility of the owner to take the responsibility to test and treat that water to avoid possible health issues [22].

Pakistan Environmental Protection Agency declared national standards for the quality of drinking water in 2008 and it was publish as an act in government of Pakistan's act rules [6].

Daud, MK, Nafees, M, Ali, S, Rizwan, M, Bajwa, RA, Shakoor, MB, Arshad, MU, Chatha, SAS, Deeba, F, Murad, W, Malook, I and Zhu, SJ conducted a bio medical research considering the international standards of quality of drinking water and compared it with Pakistan's status of quality of drinking water in 2017 [9]. They also mentioned and studied the contamination in drinking water in Pakistan and stated that contamination's status with the standards of quality of drinking water.

\section{PROPOSED SINGLE LAYERED MFIS BASED DHB EXPERT SYSTEM}

Proposed Water Quality classification,
Single-Layered Mamdani Fuzzy based Expert System is elucidated in this section. The Figure 1. Shows the flow of proposed Expert System methodology. Proposed Expert System consists of a single layer. In it we classify water by using fifteen input variables which are mostly periodic elements and some are the characteristics of water such as Turbidity, Hardness, pH, TDS, Color. The value of periodic elements and characteristic elements are also used in to build this Expert System.

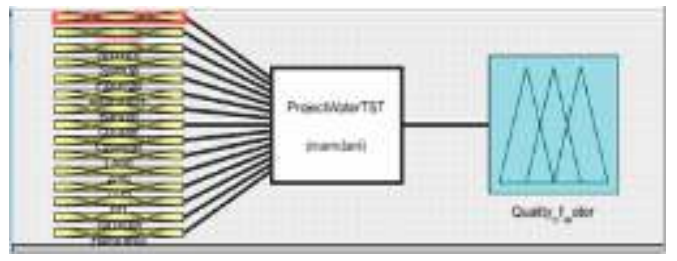

Fig 1: System of example watersheds for the study

\section{INPUT FUZZY SETS}

Fuzzy input variables are statistical values that are used to check the quality of water. In this article, total fifteen different types of input variables are used to check the quality of water. In which 10 are periodic elements and five are the characteristic elements of water shown in Table 1.

Table 1: Layer-I input variable of Proposed MLMFIS-DHB Expert System

\begin{tabular}{|c|c|c|c|}
\hline Elements & Normal & Best & Unsuitable \\
\hline Aluminum & NULL & $\begin{array}{c}0- \\
0.2^{0}\end{array}$ & $>=0.2$ \\
\hline Barium & NULL & $\begin{array}{l}0.65 \\
-1\end{array}$ & $\begin{array}{l}<0.71 \\
>0.98\end{array}$ \\
\hline Chloride & $\begin{array}{c}230- \\
1000\end{array}$ & $\begin{array}{l}<25 \\
0\end{array}$ & $>=1000$ \\
\hline Color & NULL & $0-15$ & $>=14.5$ \\
\hline Copper & $\begin{array}{l}0.04-2 \\
2-30\end{array}$ & $2.2^{1.8-}$ & $\begin{array}{l}<=0.05, \\
>29.8\end{array}$ \\
\hline Cyanide & $\begin{array}{l}0.049- \\
0.07\end{array}$ & $\begin{array}{c}0- \\
0.05\end{array}$ & $>0.068$ \\
\hline Fluoride & $\begin{array}{l}0.59- \\
1.52\end{array}$ & $\begin{array}{l}\mathrm{NU} \\
\mathrm{LL}\end{array}$ & $\begin{array}{r}\quad<0.63, \\
>1.475\end{array}$ \\
\hline Hardness & $\begin{array}{l}499- \\
600\end{array}$ & $\begin{array}{c}99- \\
499\end{array}$ & $\begin{array}{l}<=100 \\
>598\end{array}$ \\
\hline Lead & $\begin{array}{l}0.049- \\
0.5\end{array}$ & $\begin{array}{r}0.00 \\
9-0.05\end{array}$ & $\begin{array}{l}<=0.01, \\
>0.48\end{array}$ \\
\hline Turbidity & $4.5-25$ & $\begin{array}{c}0- \\
4.9 \\
\end{array}$ & $>=24.5$ \\
\hline pH & $\begin{array}{l}8.5- \\
9.3\end{array}$ & $\begin{array}{l}6.5- \\
8.6\end{array}$ & $<6.7,>9.1$ \\
\hline Sodium & NULL & $\begin{array}{c}1- \\
200 \\
\end{array}$ & $<=1,>198$ \\
\hline Sulfate & NULL & $\begin{array}{c}0- \\
500\end{array}$ & $<=1,>498$ \\
\hline TDS & NULL & $\begin{array}{c}0- \\
999 \\
\end{array}$ & $>998$ \\
\hline Zinc & $\begin{array}{r}0.009- \\
4.9,5-10 \\
\end{array}$ & $\begin{array}{l}4.9- \\
5.1\end{array}$ & $\begin{array}{l}<=0.01, \\
>9.8\end{array}$ \\
\hline
\end{tabular}




\section{OUTPUT FUZZY SETS}

The output variable is the quality of water which is then consist of 3 characteristics, Healthy, Normal and Unhealthy to check whether the water is drinkable or not or is healthy, which is judged by the rules set to conclude the quality.

Table 2: Output variable of proposed MLMFIS-DHB Expert System

\begin{tabular}{|l|c|c|}
\hline \multirow{3}{*}{1} & Quality & Healthy \\
\cline { 3 - 3 } & Of & Normal \\
\cline { 3 - 3 } & Water & Unhealthy \\
\hline
\end{tabular}

\section{MEMBERSHIP FUNCTIONS}

The proposed Expert System are establish with the help of four Standard membership functions are used. Which are given below:
1. Triangular Function (Trimf)
2. S-Shaped Membership Function (SMF)
3. Z-Shaped Membership Function (ZMF)
4. Trapezoidal Function (Trapmf)

Mathematical \& graphical representations of above disused $\mathrm{MF}$ are given in Table 3. Graphical and mathematical representation of Proposed Expert System exposed in Table -4. These MF are developed after the gathering data from previous done researches on quality of water in Pakistan and following the standards set by World's Health Organization (WHO).

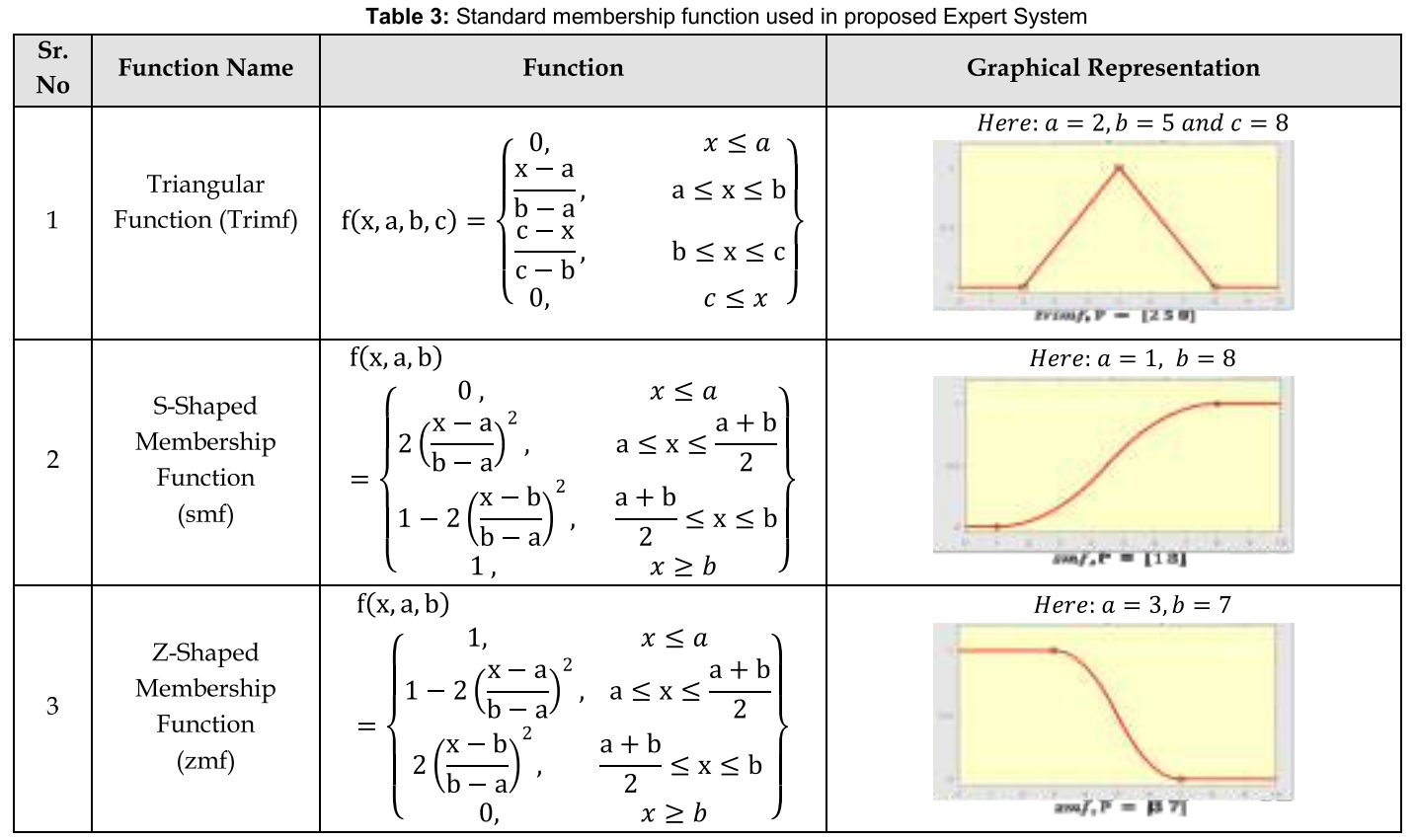




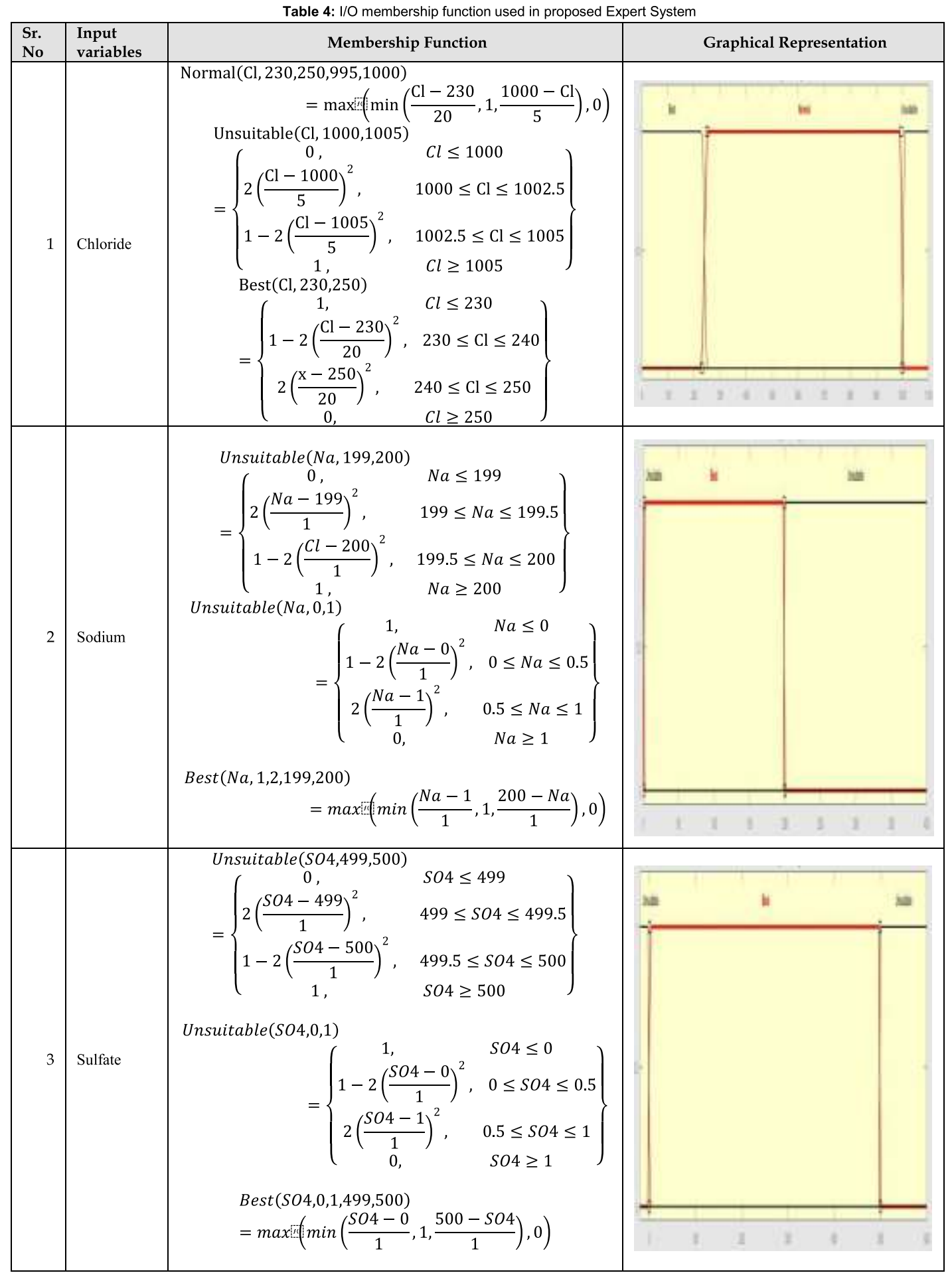




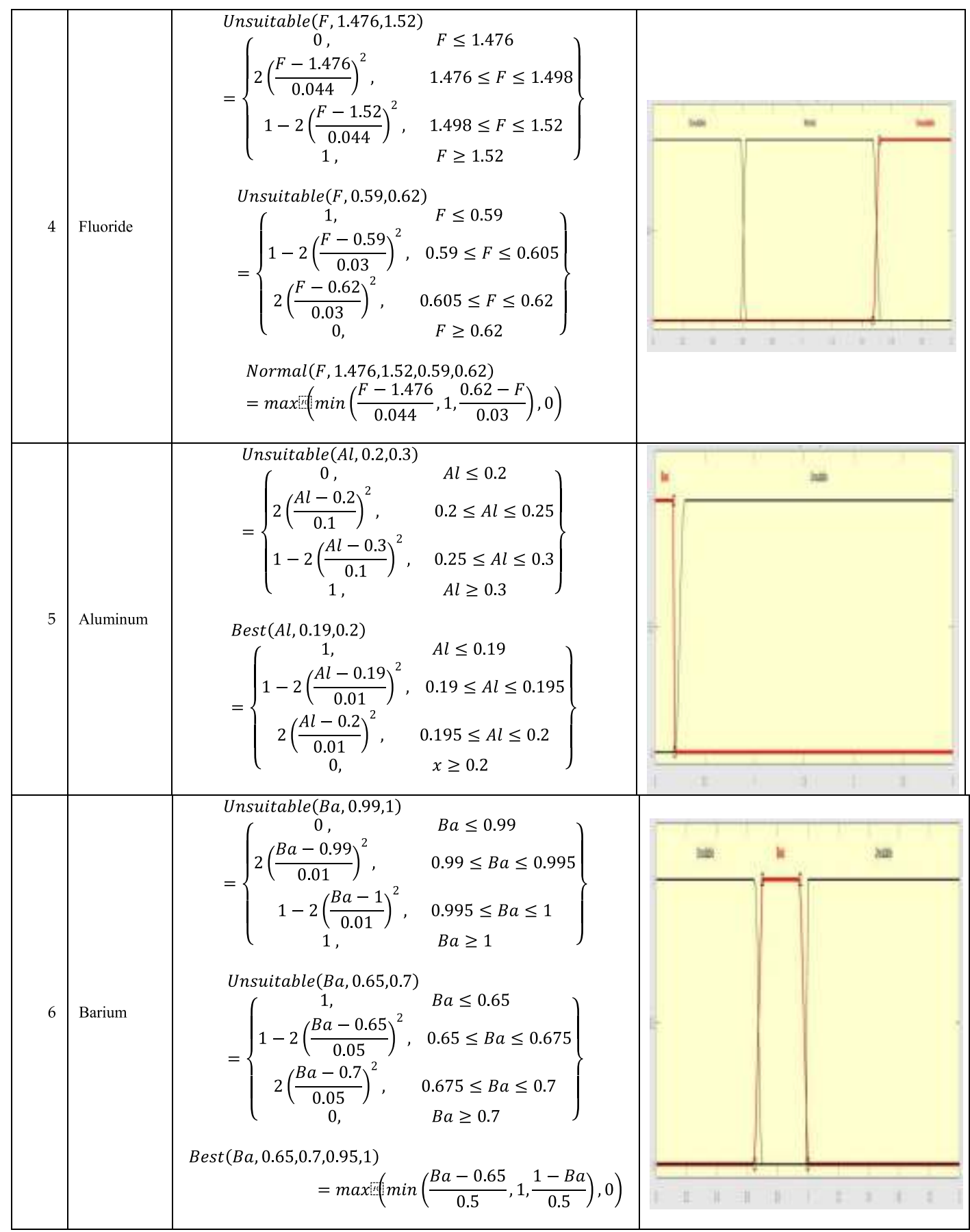




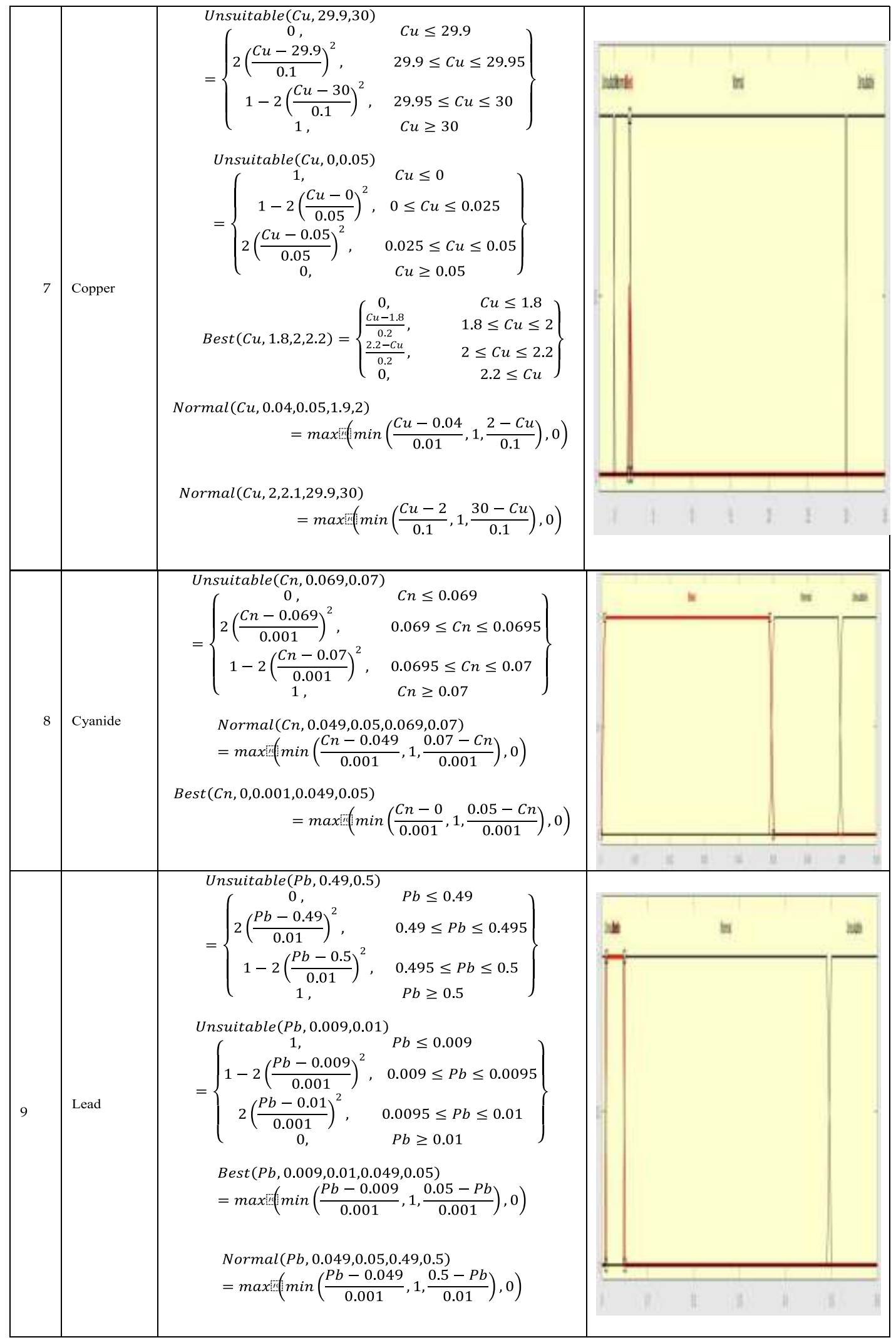




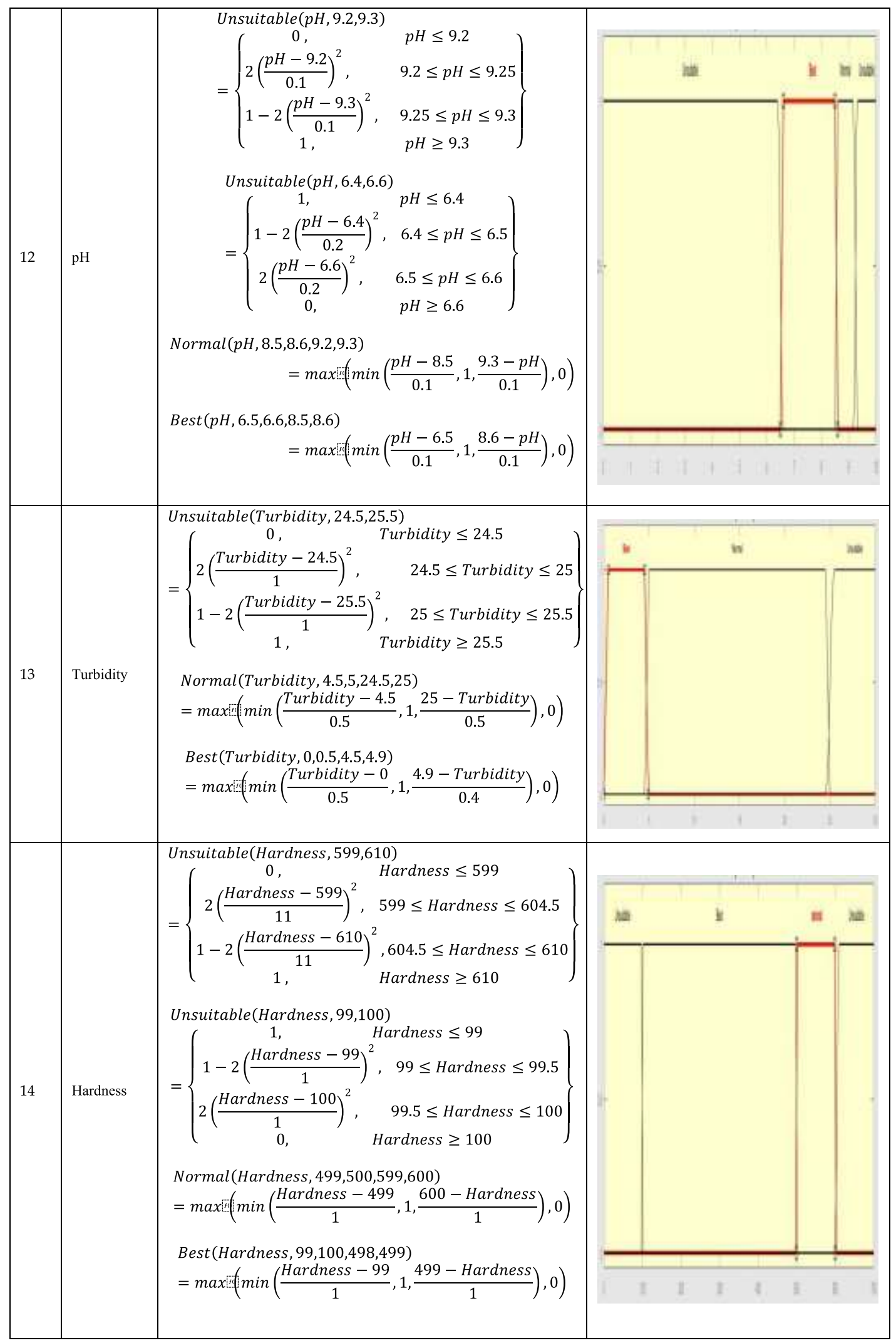




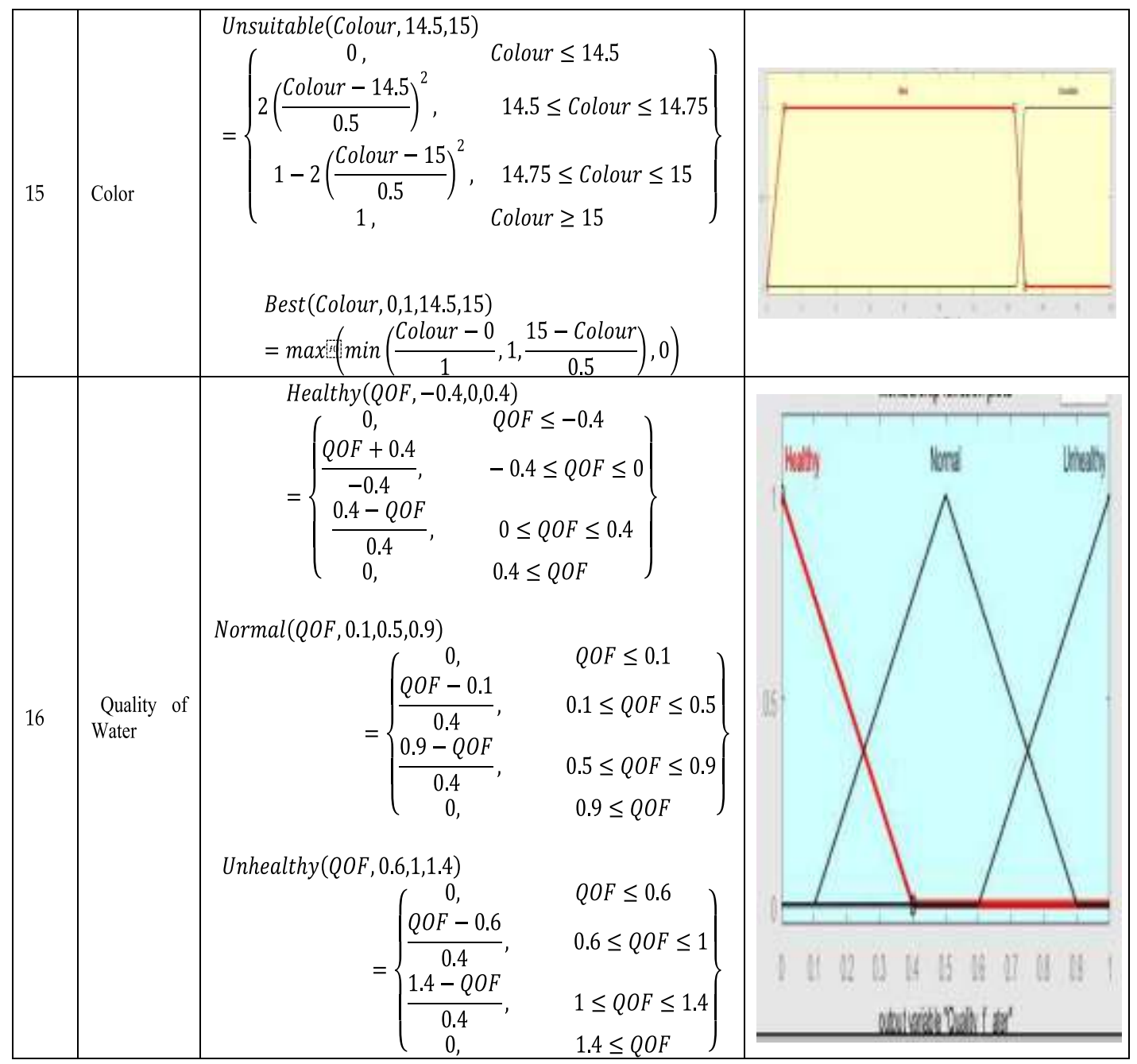

\section{LOOKUPTABLE}

This lookup table is developed after the gathering data from previous done researches on quality of water in Pakistan and following the standards set by WHO.

Table 5: Look up Table for Proposed DHB-ML-MFIS based HB

\begin{tabular}{|c|c|c|c|c|c|c|c|c|c|c|c|c|c|c|c|c|}
\hline Rules & $\mathrm{Cl}$ & $\mathrm{Na}$ & $\mathrm{SO} 4$ & $\mathrm{~F}$ & $\mathrm{Al}$ & $\mathrm{Ba}$ & $\mathrm{Cu}$ & $\mathrm{Cn}$ & $\mathrm{Pb}$ & $\mathrm{Zn}$ & TDS & $\mathrm{pH}$ & Turbidity & Hardness & Color & Quality Of Water \\
\hline & $B$ & $\mathrm{~B}$ & B & $\mathrm{N}$ & $\mathrm{B}$ & $B$ & B & B & $B$ & B & B & B & $\mathrm{B}$ & $\mathrm{B}$ & B & Healthy \\
\hline & B & $B$ & $B$ & $\mathrm{~N}$ & $B$ & 1 & $\mathrm{~N}$ & $\mathrm{~B}$ & $\mathrm{~N}$ & B & $\mathrm{B}$ & $B$ & $\mathrm{~B}$ & $B$ & $B$ & Healthy \\
\hline & $\mathrm{B}$ & $\mathrm{B}$ & $B$ & $\mathrm{~N}$ & $B$ & $\mathrm{~N}$ & B & $\mathrm{B}$ & $\mathrm{B}$ & 1 & $B$ & $B$ & $\mathrm{~B}$ & $\mathrm{~B}$ & $\mathrm{~B}$ & Healthy \\
\hline & $\mathrm{N}$ & $B$ & $B$ & $\mathrm{~N}$ & $B$ & $B$ & 1 & $B$ & $B$ & B & $B$ & $B$ & $\mathrm{~N}$ & $B$ & $B$ & Healthy \\
\hline & B & B & $B$ & $\mathrm{~N}$ & $\mathrm{~B}$ & B & $\mathrm{N}$ & B & 1 & B & $\mathrm{B}$ & $\mathrm{N}$ & $\mathrm{B}$ & $\mathrm{B}$ & B & Healthy \\
\hline & $\mathrm{N}$ & $B$ & $\mathrm{U}$ & $\mathrm{N}$ & 1 & B & $B$ & $B$ & $B$ & $\mathrm{~N}$ & B & $B$ & B & $\mathrm{N}$ & $B$ & Normal \\
\hline & B & B & $B$ & $\mathrm{~N}$ & $\mathrm{~B}$ & $\mathrm{U}$ & $\mathrm{N}$ & $B$ & 1 & $B$ & $B$ & $B$ & $\mathrm{~N}$ & $B$ & $B$ & Normal \\
\hline & 1 & $\mathrm{U}$ & $B$ & $\mathrm{~N}$ & $B$ & $B$ & $B$ & $\mathrm{~N}$ & B & $\mathrm{N}$ & $B$ & $B$ & B & $\mathrm{N}$ & $B$ & Normal \\
\hline & $B$ & $B$ & 1 & $\mathrm{~N}$ & $B$ & $B$ & $\mathrm{~N}$ & $\mathrm{~N}$ & $B$ & $B$ & $\mathrm{U}$ & $\mathrm{N}$ & $B$ & $B$ & $B$ & Normal \\
\hline & $\mathrm{N}$ & 1 & $B$ & $\mathrm{~N}$ & $\mathrm{U}$ & $B$ & $B$ & B & $\mathrm{N}$ & $\mathrm{N}$ & B & $B$ & $\mathrm{~N}$ & $B$ & B & Normal \\
\hline & $B$ & B & $\mathrm{U}$ & $\mathrm{N}$ & $\mathrm{B}$ & $B$ & $\mathrm{U}$ & $B$ & $B$ & $B$ & $\mathrm{U}$ & $\mathrm{N}$ & $\mathrm{B}$ & 1 & U & Unhealthy \\
\hline & $\mathrm{N}$ & $B$ & $B$ & $\mathrm{U}$ & $B$ & $B$ & $B$ & $\mathrm{U}$ & $B$ & $\mathrm{~N}$ & B & $\mathrm{N}$ & $\mathrm{U}$ & $\mathrm{U}$ & 1 & Unhealthy \\
\hline & $\mathrm{N}$ & $B$ & $\mathrm{~B}$ & $\mathrm{~N}$ & $\mathrm{~B}$ & $\mathrm{U}$ & $B$ & 1 & $B$ & $\mathrm{U}$ & $\mathrm{B}$ & B & 1 & $B$ & $\mathrm{U}$ & Unhealthy \\
\hline & $B$ & $\mathrm{U}$ & $\mathrm{U}$ & $\mathrm{N}$ & $B$ & $B$ & $\mathrm{~N}$ & B & $\mathrm{N}$ & $B$ & 1 & $\mathrm{U}$ & $B$ & $\mathrm{~N}$ & $B$ & Unhealthy \\
\hline & $\mathrm{U}$ & 1 & $B$ & $\mathrm{U}$ & $\mathrm{U}$ & $B$ & $\mathrm{U}$ & 1 & $\mathrm{~B}$ & B & B & $\mathrm{N}$ & $\mathrm{N}$ & $\mathrm{U}$ & B & Unhealthy \\
\hline
\end{tabular}




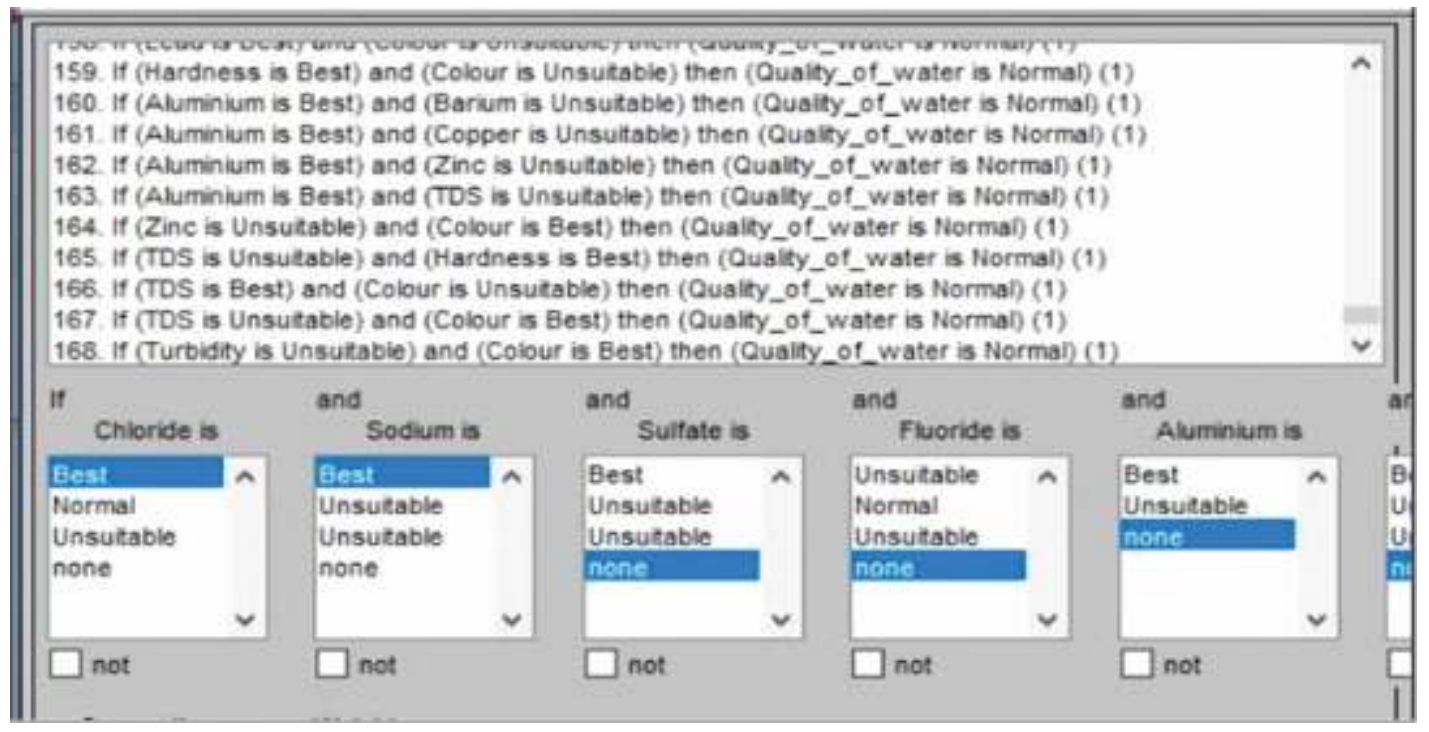

10. DE-FUZZIFIER

The quality of water results are the combination of at least 13 input variables.

Figure $3 \mathrm{a}, 3 \mathrm{~b}$ and $3 \mathrm{~g}$ represent the rule surface with the combination input variable that are periodic elements, to get the output as the values of quality of water. Common thing in the resulted rule surface for Figure $3 a, 3 b, 3 c$ is that $30 \%$ to $50 \%$ of the output is grounded to 0 probability values.

Figure $3 \mathrm{c}, 3 \mathrm{~d}, 3 \mathrm{e}$ and $3 \mathrm{f}$ represent the rule surface with the combination of periodic elements and characteristic elements, to get the

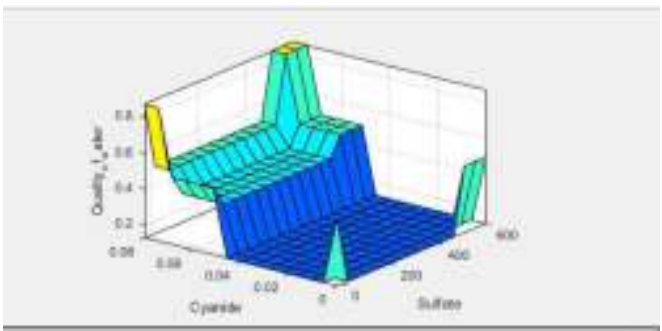

Figure 3a. Rule Surface for Cyanide and Sulfate

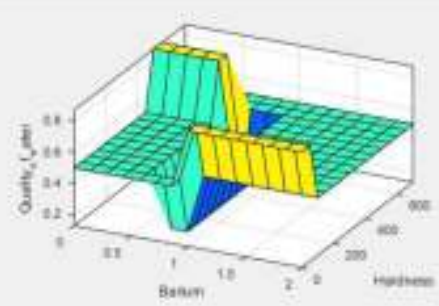

Figure 3c. Rule Surface for Barium and Hardness

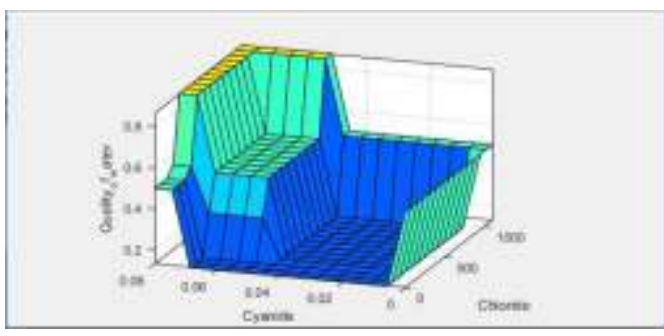

Figure 3b. Rule Surface for Chloride and Cyanide

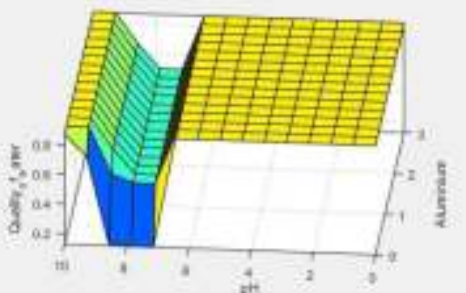

Figure 3d. Rule Surface for Aluminum and $\mathrm{pH}$ 


\section{SIMULATION RESULTS}

For simulation results, MATLAB $\mathrm{R} 2017 \mathrm{a}$ tool is used. MATLAB is also used for modeling, simulation, algorithm development, prototyping and many other fields. MATLAB is an efficient tool for programming, data analysis, visualization and computing. For simulation results, fifteen inputs and one output Quality Of Water variables are used. In this article, the proposed Expert System only diagnose whether the water is Healthy, Normal or Unhealthy. In this analysis, we concluded it as truth table with the combination of, best, normal and unsuitable parameter and ranges of input variable to and evaluating it to get the quality of water.

Below we are comparing Chloride and
Cyanide; both of them are periodic elements, we compare their parameters with different combinations as if in a truth table and concluded the quality of water. In Figure 1 as we can see that the element Chloride is at the middle of a best range and as if the Cyanide is also at its best range so we get the quality of water as healthy and triangle making a 90 degree angle at left is lighted up. As the left 90 degree angle triangle represents Healthy.

Centered triangle represents normal and right 90 degree angled triangle represents unhealthy, so we know that quality of water is healthy in this specific case. Other cases below defines the quality of water depending on the range of the elements set in input.

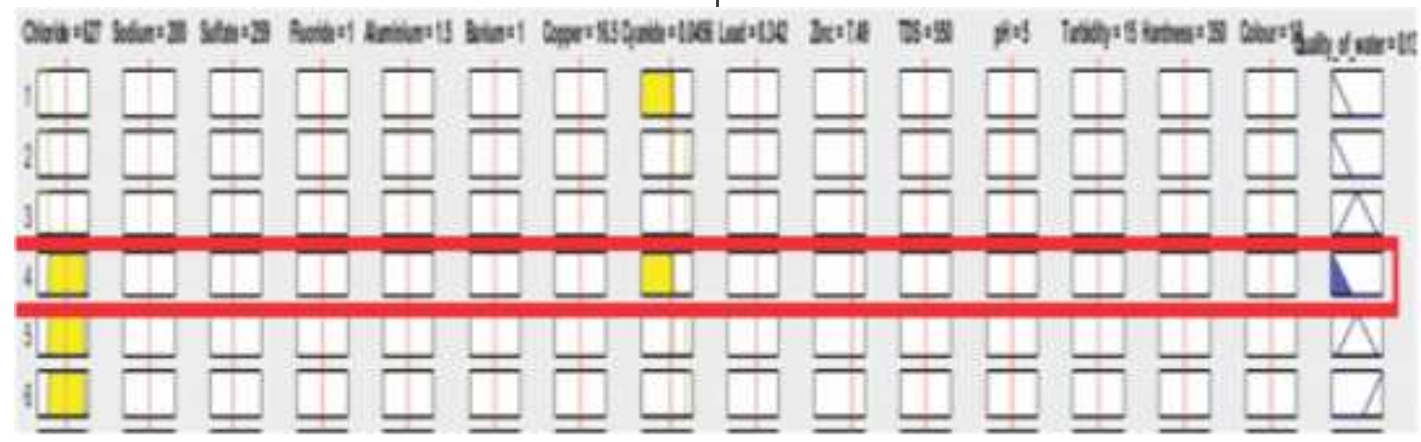

Fig 4a. Lookup diagram for Healthy Water

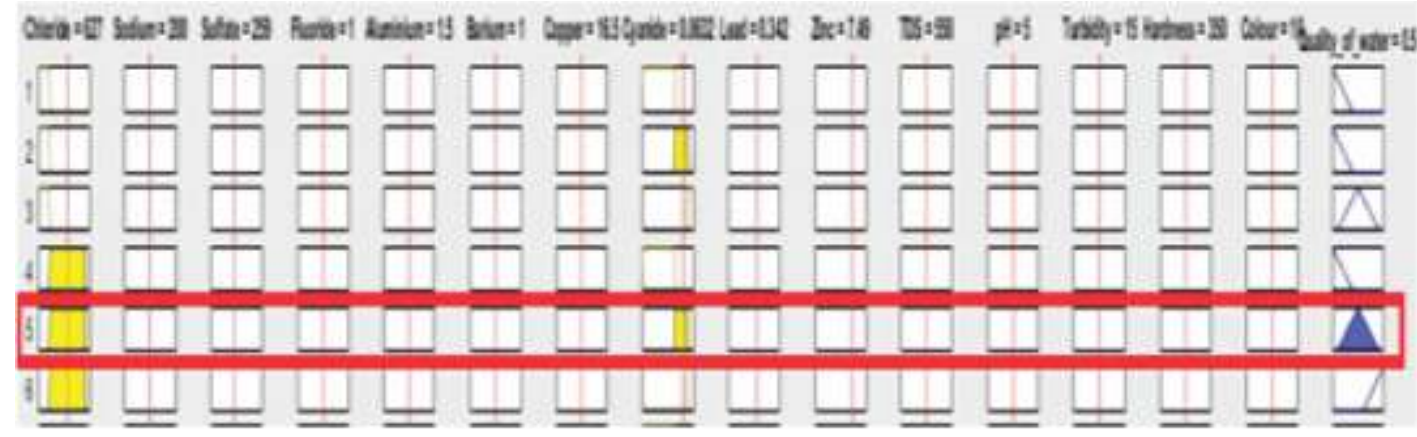

Fig 4b. Lookup diagram for Normal Water

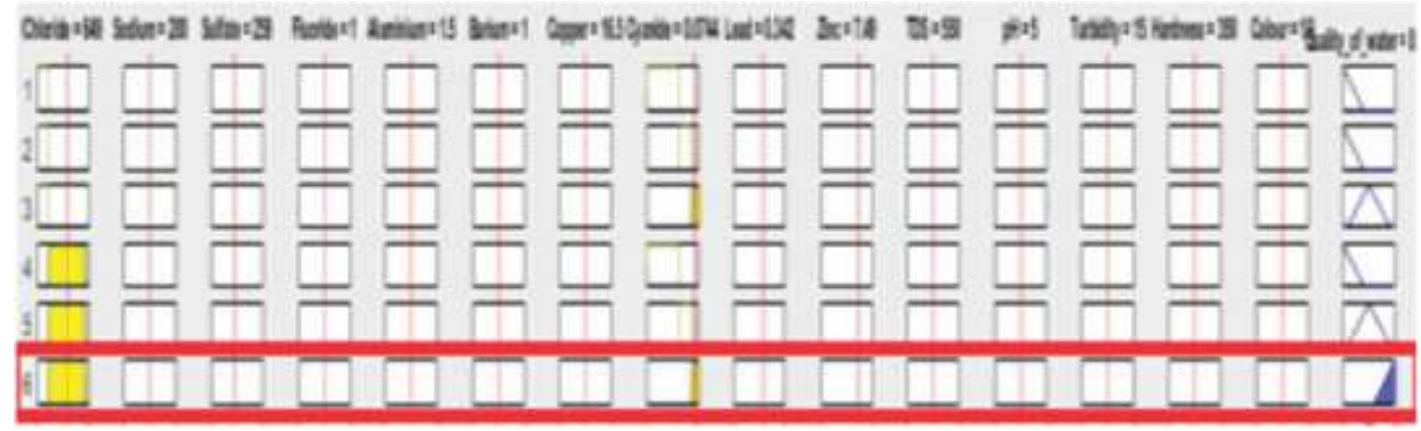

Fig 4c. Lookup diagram for Unhealthy Water 
Table 6: Accuracy of Proposed DHB-ML-MFIS Expert System

\begin{tabular}{|c|c|c|c|c|c|c|c|c|c|c|c|c|c|c|c|c|c|c|c|}
\hline $\begin{array}{l}\text { Ele } \\
\text { men } \\
\text { ts }\end{array}$ & $\mathrm{Cl}$ & $\mathrm{Na}$ & So4 & F & $\mathrm{Al}$ & Ва & $\mathrm{Cu}$ & $\mathrm{Cn}$ & $\mathrm{Pb}$ & $\mathrm{Zn}$ & TDS & $\mathrm{pH}$ & $\begin{array}{c}\text { Turbidit } \\
\text { y }\end{array}$ & $\begin{array}{c}\text { Hardnes } \\
\text { s }\end{array}$ & $\begin{array}{c}\text { Colo } \\
\mathrm{r}\end{array}$ & $\begin{array}{l}\text { Hum } \\
\text { an } \\
\text { Expe } \\
\text { rt } \\
\text { Decis } \\
\text { ion }\end{array}$ & $\begin{array}{c}\text { Proposed } \\
\text { QOW } \\
\text { Expert } \\
\text { System } \\
\text { Decision }\end{array}$ & $\begin{array}{l}\text { Probab } \\
\text { ility of } \\
\text { Correc } \\
\text { tness }\end{array}$ & $\begin{array}{l}\text { Probab } \\
\text { ility of } \\
\text { Error's }\end{array}$ \\
\hline 1 & $\begin{array}{c}\text { B } \\
200\end{array}$ & $\begin{array}{c}\text { B } \\
100\end{array}$ & $\begin{array}{c}\text { B } \\
290\end{array}$ & $\begin{array}{c}\mathrm{N} \\
1 \\
\end{array}$ & $\begin{array}{c}\mathrm{B} \\
0.1\end{array}$ & $\begin{array}{c}\mathrm{B} \\
0.8\end{array}$ & $\begin{array}{c}\mathrm{B} \\
1.9\end{array}$ & $\begin{array}{c}\text { B } \\
0.04\end{array}$ & $\begin{array}{c}\mathrm{B} \\
0.03\end{array}$ & $\begin{array}{c}\mathrm{B} \\
4.5\end{array}$ & $\begin{array}{c}\mathrm{B} \\
550\end{array}$ & $\begin{array}{c}\mathrm{B} \\
7.5\end{array}$ & $\begin{array}{l}\text { B } \\
4\end{array}$ & $\begin{array}{c}\mathrm{B} \\
350\end{array}$ & $\begin{array}{c}\text { B } \\
10\end{array}$ & \multirow{19}{*}{$\begin{array}{c}\text { H } \\
\text { E } \\
\mathbf{A} \\
\text { L } \\
\text { T } \\
\text { H } \\
\text { Y }\end{array}$} & Healthy & \multirow{19}{*}{0.8} & \multirow{19}{*}{0.2} \\
\hline 2 & B & $B$ & B & $\mathrm{N}$ & B & 1 & $\mathrm{~N}$ & B & $\mathrm{N}$ & B & $\mathrm{B}$ & B & B & B & B & & Healthy & & \\
\hline & 210 & 95 & 222 & 1.2 & 0.01 & & 4.5 & 0.01 & 0.4 & 4.91 & 100 & 7 & 3.5 & 150 & 2 & & Healtny & & \\
\hline \multirow{2}{*}{3} & B & B & B & $\mathrm{N}$ & B & B & B & B & B & 1 & B & B & B & B & B & & & & \\
\hline & 98 & 63 & 199 & 0.9 & 0.1 & 0.8 & 2 & 0.02 & 0.04 & & 135 & 7.2 & 3.5 & 150 & 2 & & Healthy & & \\
\hline \multirow{2}{*}{4} & $\mathrm{~N}$ & B & B & $\mathrm{N}$ & B & B & 1 & B & B & B & B & B & $\mathrm{N}$ & B & B & & Normal & & \\
\hline & 240 & 199 & 495 & 0.9 & 0.2 & 0.8 & & 0.02 & 0.049 & 4.95 & 999 & 6.6 & 4.8 & 122 & 14.8 & & Normal & & \\
\hline \multirow{2}{*}{5} & B & $\mathrm{B}$ & B & $\mathrm{N}$ & B & B & $\mathrm{N}$ & B & 1 & B & B & $\mathrm{N}$ & B & B & B & & Healthy & & \\
\hline & 220 & 96 & 300 & 1.4 & 0.1 & 0.68 & 4.2 & 0.39 & & 5 & 891 & 8.8 & 4.8 & 380 & 13.5 & & Healtny & & \\
\hline \multirow[b]{2}{*}{6} & B & B & $\mathrm{B}$ & $\mathrm{N}$ & B & B & $\mathrm{N}$ & $B$ & B & 1 & $\mathrm{~B}$ & $\mathrm{~N}$ & $\mathrm{~B}$ & $\mathrm{~B}$ & B & & Healthy & & \\
\hline & 220 & 96 & 300 & 1.4 & 0.1 & 0.68 & 4.2 & 0.39 & 0.04 & & 891 & 8.9 & 4.8 & 380 & 13 & & 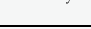 & & \\
\hline \multirow[b]{2}{*}{7} & B & $\mathrm{B}$ & B & $\mathrm{N}$ & B & B & $B$ & B & 1 & $\mathrm{~N}$ & $\mathrm{~B}$ & $\mathrm{~N}$ & B & $B$ & $B$ & & & & \\
\hline & 115 & 45 & 499 & 0.62 & 0.1 & 0.68 & 2 & 0.05 & & 5 & 132 & 9 & 4.8 & 499 & 4 & & Normal & & \\
\hline \multirow[b]{2}{*}{8} & $\mathrm{~N}$ & B & $B$ & $\mathrm{~N}$ & B & $\mathrm{B}$ & B & $B$ & B & $B$ & $B$ & $\mathrm{~N}$ & $\mathrm{~B}$ & B & B & & & & \\
\hline & 800 & 63 & 199 & 1.3 & 0.02 & 0.8 & 2.2 & 0.02 & 0.04 & 4.95 & 130 & 9 & 2 & 122 & 4 & & Healthy & & \\
\hline \multirow{2}{*}{9} & B & B & B & $\mathrm{N}$ & B & B & B & $\mathrm{N}$ & B & B & B & B & B & B & B & & & & \\
\hline & 140 & 96 & 300 & 1.4 & 0.1 & 0.68 & 2.1 & 0.06 & 0.04 & 4.95 & 130 & 8 & 4.3 & 380 & 6 & & Healthy & & \\
\hline 10 & $\mathrm{~N}$ & B & B & $\mathrm{N}$ & B & B & $\mathrm{N}$ & B & B & B & B & $\mathrm{N}$ & $\mathrm{N}$ & B & B & & Healthy & & \\
\hline 10 & 700 & 100 & 200 & 0.9 & 0.06 & 0.8 & 0.06 & 0.039 & 0.03 & 4.96 & 200 & 8.9 & 20 & 222 & 8 & & Healthy & & \\
\hline 11 & $\mathrm{~N}$ & B & $\mathrm{U}$ & $\mathrm{N}$ & 1 & B & B & B & B & $\mathrm{N}$ & B & B & B & $\mathrm{N}$ & B & & Normal & & \\
\hline & 600 & 100 & 600 & 1.35 & & 0.68 & 1.8 & 0.02 & 0.04 & 8.5 & 523 & 7.3 & 0.3 & 555 & 6.5 & & Normal & & \\
\hline & B & B & B & $\mathrm{N}$ & B & $\mathrm{U}$ & $\mathrm{N}$ & B & 1 & B & B & B & $\mathrm{N}$ & B & B & & & & \\
\hline 12 & 245 & 45 & 499 & 0.9 & 0.2 & 1 & 0.04 & 0.03 & & 4.98 & 200 & 8 & 4.7 & 122 & 14.8 & & Healthy & & \\
\hline 13 & 1 & $\mathrm{U}$ & $B$ & $\mathrm{~N}$ & B & B & B & $\mathrm{N}$ & $B$ & $\mathrm{~N}$ & B & B & B & $\mathrm{N}$ & $B$ & & Normal & & \\
\hline 13 & 1 & 188 & 210 & 1.43 & 0.1 & 0.32 & 2.1 & 0.01 & 0.02 & 8.3 & 791 & 8.9 & 4.8 & 500 & 12.9 & & Normal & & \\
\hline & B & B & 1 & $\mathrm{~N}$ & B & B & $\mathrm{N}$ & $\mathrm{N}$ & B & B & $\mathrm{U}$ & $\mathrm{N}$ & B & B & B & & Normal & & \\
\hline 14 & 215 & 182 & & 1.45 & 0.1 & 0.49 & 4.1 & 0.03 & 0.02 & 8.3 & 892 & 8.8 & 4.7 & 480 & 12.7 & o & Normal & & \\
\hline & $\mathrm{N}$ & 1 & B & $\mathrm{N}$ & $\mathrm{U}$ & B & B & $B$ & $\mathrm{~N}$ & $\mathrm{~N}$ & $\mathrm{~B}$ & $\mathrm{~B}$ & $\mathrm{~N}$ & B & B & D & & & \\
\hline 15 & 800 & . & 199 & 0.62 & 0.3 & 0.68 & 1.8 & 0.02 & 0.49 & 9.9 & 630 & 7.3 & 4.8 & 499 & 2 & $\mathbf{R}$ & Normal & & \\
\hline 16 & B & B & $B$ & $\mathrm{~N}$ & $\mathrm{U}$ & $B$ & $\mathrm{~N}$ & $B$ & B & $B$ & $\mathrm{~B}$ & B & $\mathrm{N}$ & $\mathrm{N}$ & B & M & Normal & 0.8 & 0.2 \\
\hline 16 & 219 & 198 & 301 & 1.5 & 0.1 & 0.89 & 4.1 & 0.39 & 0.04 & 4.8 & 891 & 8.6 & 21.4 & 500 & 12.9 & (1) & Normal & & \\
\hline & $\mathrm{N}$ & B & $\mathrm{U}$ & $\mathrm{N}$ & B & B & B & $\mathrm{U}$ & B & $\mathrm{N}$ & B & $\mathrm{N}$ & B & B & B & A & & & \\
\hline 17 & 700 & 96 & 777 & 1.3 & 0.02 & 0.8 & 2.2 & 0.8 & 0.04 & 8.5 & 500 & 8.8 & 3.2 & 200 & 9.9 & L & Normal & & \\
\hline & B & B & $\mathrm{U}$ & $\mathrm{N}$ & B & $\mathrm{U}$ & B & $\mathrm{N}$ & B & B & 1 & B & $\mathrm{B}$ & $\mathrm{N}$ & B & & & & \\
\hline 18 & 222 & 96 & 0.1 & 1.4 & 0.1 & 0.68 & 2.1 & 0.03 & 0.04 & 5 & 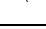 & 8.6 & 4.7 & 500 & 12.9 & & Normal & & \\
\hline 19 & $\mathrm{U}$ & B & $B$ & $\mathrm{~N}$ & B & B & $\mathrm{N}$ & B & $\mathrm{U}$ & B & B & B & $\mathrm{N}$ & B & B & & Unhealthy & & \\
\hline 19 & 1000 & 199 & 200 & 0.6 & 0.06 & 0.68 & 0.069 & 0.04 & 0.5 & 4.96 & 999 & 8 & 24.5 & 122 & 6 & & Unnealtuy & & \\
\hline & B & $\mathrm{U}$ & B & $\mathrm{N}$ & B & B & B & $\mathrm{N}$ & B & $\mathrm{N}$ & B & B & $\mathrm{N}$ & $\mathrm{N}$ & B & & & & \\
\hline 20 & 222 & 188 & 301 & 1.4 & 0.1 & 0.68 & 2.1 & 0.01 & 0.02 & 8.3 & 890 & 8.6 & 21.4 & 500 & 12.9 & & Normal & & \\
\hline & B & B & $\mathrm{U}$ & $\mathrm{N}$ & B & B & $\mathrm{U}$ & B & B & B & $\mathrm{U}$ & $\mathrm{N}$ & B & 1 & $\mathrm{U}$ & & & & \\
\hline 21 & 115 & 100 & 600 & 1.4 & 0.1 & 0.82 & 32 & 0.03 & 0.02 & 4.95 & 1111 & 8.9 & 2 & & 16 & & Unhealthy & & \\
\hline 22 & $\mathrm{~N}$ & $\mathrm{~B}$ & B & $\mathrm{U}$ & B & B & B & $\mathrm{U}$ & B & $\mathrm{N}$ & B & $\mathrm{N}$ & $\mathrm{U}$ & $\mathrm{U}$ & 1 & & & & \\
\hline 22 & 250 & 96 & 300 & 0.61 & 0.1 & 0.68 & 2.1 & 0.17 & 0.04 & 8.3 & 892 & 8.6 & 26 & 650 & 1 & & Unhealthy & & \\
\hline 23 & $\mathrm{~N}$ & B & B & $\mathrm{N}$ & B & $\mathrm{U}$ & B & 1 & B & $\mathrm{U}$ & $B$ & $\mathrm{~B}$ & 1 & B & $\mathrm{U}$ & $\mathbf{U}$ & Unhealthy & & \\
\hline & 666 & 88 & 333 & 0.9 & 0.02 & 0.68 & 1.9 & 0 & 0.04 & 11 & 555 & 7.5 & & 111 & 22 & $\mathrm{~N}$ & & & \\
\hline & $B$ & $\mathrm{U}$ & $\mathrm{U}$ & $\mathrm{N}$ & $B$ & B & $\mathrm{N}$ & B & $\mathrm{N}$ & $B$ & 1 & $\mathrm{U}$ & $\mathrm{B}$ & $\mathrm{N}$ & $\mathrm{B}$ & $\mathbf{N}$ & & & \\
\hline 24 & 220 & 288 & 0.1 & 1.4 & 0.1 & 0.68 & 4.2 & 0.04 & 0.45 & 8.3 & & 9.4 & 4.7 & 500 & 12.9 & $\mathbf{H}$ & Unhealthy & & \\
\hline 25 & $\mathrm{U}$ & 1 & $B$ & $\mathrm{U}$ & $\mathrm{U}$ & B & $\mathrm{U}$ & 1 & B & $B$ & $\mathrm{~B}$ & $\mathrm{~N}$ & $\mathrm{~N}$ & $\mathrm{U}$ & B & $\mathrm{F}$ & Normal & & \\
\hline 20 & 1000 & 1 & 199 & 1.48 & 0.2 & 0.8 & 29.9 & & 0.03 & 4.98 & 200 & 8.5 & 25 & 599 & 6.5 & E & Normar & & \\
\hline & $\mathrm{N}$ & $\mathrm{U}$ & $\mathrm{U}$ & $\mathrm{N}$ & B & $\mathrm{U}$ & $\mathrm{N}$ & $\mathrm{U}$ & $\mathrm{N}$ & $\mathrm{U}$ & B & $\mathrm{U}$ & $\mathrm{U}$ & $B$ & $\mathrm{U}$ & A & & 0.8 & 0.2 \\
\hline 26 & 250 & 388 & 0.1 & 1.4 & 0.1 & 0.68 & 4.1 & 0.17 & 0.45 & 0.12 & 891 & 9.4 & 26 & 480 & 16 & $\mathrm{~L}$ & Unhealthy & & \\
\hline & $\mathrm{U}$ & B & B & $\mathrm{U}$ & B & B & $\mathrm{U}$ & $\mathrm{N}$ & $\mathrm{U}$ & B & $\mathrm{U}$ & $\mathrm{N}$ & $\mathrm{N}$ & $\mathrm{U}$ & B & L & & & \\
\hline 27 & 1011 & 182 & 300 & 0.61 & 0.1 & 0.68 & 35 & 0.03 & 0.7 & 4.92 & 1000 & 8.8 & 8.6 & 26 & 12.9 & $\mathrm{~T}$ & Unhealthy & & \\
\hline 28 & B & $\mathrm{U}$ & B & $\mathrm{U}$ & B & $\mathrm{U}$ & B & $\mathrm{U}$ & $\mathrm{N}$ & $\mathrm{U}$ & B & B & $\mathrm{U}$ & $\mathrm{N}$ & B & H & Unhealthy & & \\
\hline 28 & 600 & 1 & 455 & 0.3 & 0.15 & 0.68 & 2.1 & 0.8 & 0.4 & 11 & 555 & 7.8 & 26 & 500 & 8.5 & 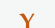 & Unnealtuy & & \\
\hline & $\mathrm{U}$ & B & $\mathrm{U}$ & $\mathrm{N}$ & $\mathrm{U}$ & B & $\mathrm{U}$ & B & $\mathrm{N}$ & $\mathrm{N}$ & $\mathrm{U}$ & $\mathrm{U}$ & B & B & $\mathrm{U}$ & $\mathbf{Y}$ & & & \\
\hline 29 & 1212 & 95 & 666 & 1 & 0.3 & 0.77 & 33 & 0.04 & 0.45 & 4 & 1000 & 3.5 & 3.3 & 150 & 17 & & Unnealthy & & \\
\hline 30 & $\begin{array}{c}\mathrm{U} \\
1000\end{array}$ & $\begin{array}{c}\mathrm{B} \\
63\end{array}$ & $\begin{array}{c}\text { U } \\
499\end{array}$ & $\begin{array}{c}U \\
0.62\end{array}$ & $\begin{array}{c}\text { B } \\
0.06\end{array}$ & $\begin{array}{c}\text { B } \\
0.75\end{array}$ & $\begin{array}{c}\mathrm{U} \\
0.04\end{array}$ & $\begin{array}{c}\text { B } \\
0.038\end{array}$ & $\begin{array}{c}\mathrm{U} \\
0.49\end{array}$ & $\begin{array}{c}\mathrm{B} \\
4.99\end{array}$ & $\begin{array}{c}\mathrm{B} \\
222\end{array}$ & $\begin{array}{c}\mathrm{U} \\
6.6\end{array}$ & $\begin{array}{c}\text { B } \\
2.2\end{array}$ & $\begin{array}{l}\mathrm{U} \\
100\end{array}$ & $\begin{array}{c}\mathrm{B} \\
2.5\end{array}$ & & Normal & & \\
\hline
\end{tabular}

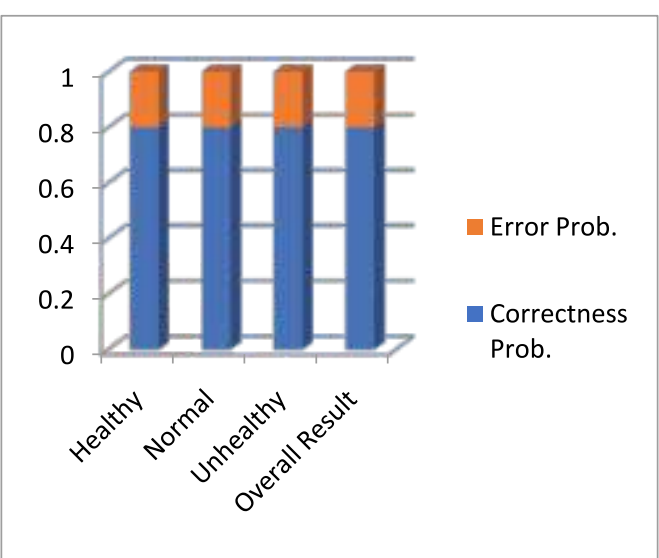

Fig 5: Accuracy of Proposed DHB-ML-MFIS Expert System

\section{CONCLUSION \& FUTURE WORK}

The primary focus of this article is to design an expert system to check the quality of water either it is healthy, normal or unhealthy by keeping account of some periodic elements in water that exist due some natural influence or by human interaction and also keep some characteristic elements in water that defines the water for the best of its quality, those are hardness, turbidity, TDS, $\mathrm{pH}$ and color so far covered in our research. Our basic objective was to conclude these mention factors that either they are in the range of safety parameters or not and also set some of the parameter on which the previous researches in Pakistan are lacking. 
Finally we concluded the research for the betterment of the quality parameters of water in Pakistan by following international standards and the guideline given by WHO and also keeping in mind the previous researches conducted on the quality of water. In future the current research could be taken to a next level by conducting another research which will be depending on this research, in which we can figure out what element should be added in water to balance the water to normal or healthy level if any of the elements exceeds the safety level. This is our next milestone and we hope that our research may help in the betterment of mankind and improve the safety of drinkable water resources provided to human.

\section{REFERENCES}

[1] BGS, Groundwater quality: Pakistan. British Geological Survey, Nottingham, 2001.

[2] Laghari, A.N. \& Vanham, D. and Rauch, W., The Indus basin in the framework of current and future water resources management, 2012. Hydrological Processes 29(11): 2613-2627.

[3] Asiam. T, Akram. F; Faroque. M, Technical Assessment Survey. Report of Water Supply Schemes. Punjab Province (Part-I). Provision of Safe Drinking Water. Pakistan Council of Research in Water Resources. Ministry of Science and Technology, 2011.

[4] Qureshi, A. S., McCornick, P. G., Sarwar, A. \& Sharma, B. R., Challenges and Prospects of Sustainable Groundwater Management in the Indus Basin, Pakistan, 2009. Water Resources Management 24(8), 15511569.

[5] Qureshi, A.S., McCornick P.G., Qadir M. \& Aslam Z., Managing salinity and waterlogging in the Indus basin in Pakistan, 2008. Agricultural Water Management 95, 1-10.

[6] WWF, Situation analysis of the water resources of Lahore. WWF-Pakistan, 2014.

[7] Aslam, A, Assessment of Pakistan national drinking water quality standards (NDWQSs), Sustainable Development Policy Institute (SDPI), Islamabad, Pakistan, 2016.

[8] Khawaja, M. A, Yasmin, F and Habib, K,
Access to safe drinking water in city slums through household water treatment systems, Sustainable Development Policy Institute (SDPI), Islamabad. Pakistan, 2011.

[9] Smith, AH, and Steinmaus, CM, Health effects of Arsenic and Chromium in drinking water, 2009.

[10] Sulehria, AQK, Mustafa, YS, Kanwal, B, and Nazish, A, Assessment of drinking water in Islampura, Lahore district, Science International, 2013 ,vol. 25, no. 2, pp. 359-361

[11] Haydar, S, Arshad, M and Aziz, JA, Evaluation of drinking water quality in urban areas of Pakistan: A case study of southern Lahore. Pakistan journal of engineering and applied sciences,2009,vol. 5, pp. 16-23

[12] Pakistan Environmental Protection Agency, National standards for drinking water q u a 1 i t y, $2008, \quad$ R e t r i e v e d fromhttp://www.environment.gov.pk/actrules/DWQStd-MAY2007.pdf.

[13] Tahir, MA, Rasheed, $\mathrm{H}$ and Imran, S, Water Quality Status in Rural Areas of Pakistan, 2010.

[14] Pakistan Environmental Protection Agency, National standards for drinking water q u a 1 i t y, 2008 . R e t r i e v e d fromhttp://www.environment.gov.pk/actrules/ DWQStd-MAY2007.pdf.

[15] Daud, MK, Nafees, M, Ali, S, Rizwan, M, Bajwa, RA, Shakoor, MB, Arshad, MU, Chatha, SAS, Deeba, F, Murad, W, Malook, I and Zhu, SJ , "Drinking Water Quality Status and Contamination in Pakistan - A Review," Bio Med Research International, 2017.

[16] Water Clinic 003 Turbidity, Color, Odor a $\mathrm{n} \mathrm{d} \quad \mathrm{T}$ a s t e. http://www.thewaterclinic.com/turbidity_color _odor_taste.html.

[17] Tahir, M.A et al, Survey of Drinking Water Quality in the Rural Areas of Rawalpindi District. Pakistan Council of Research in Water Resources, Islamabad, Pakistan, 1994.

[18] SDWF Drinking Water Quality and Health. Safe Drinking Water Foundation. 
http://www.safewater.org/members/teachers/w ater $\% 20$ and $\% 20$ health.com, 2003.

[19] PSI, Pakistan Standards 1932-1987 Specification for Drinking Water. Pakistan Standard Institution, Karachi, Pakistan, 1987.

[20] Saunders and war ford, potential economic effects and health effects of rural water supply systems. Macro economic effects, 1976.

[21] World Development Report, economic impacts of clean water, 1994.
[22] Zaslow, Herman effect of contaminants present in drinking water, 1996.

[23] Feng, M., Sexton, J.O., Channan, S., \& Townshend, J.R. (2015). A global, highresolution $(30-\mathrm{m})$ inland water body dataset for 2000: First results of a topographic-spectral classification algorithm. International Journal of Digital Earth, 1-21.

[24] Verpoorter, C., Kutser, T., Seekell, D.A., \& Tranvik, L.J. (2014). A global inventory of lakes based on high-resolution satellite imagery. Geophysical Research Letters,41,63966402. 